\title{
Duaya İlişkin Algılar: Metaforik Bir Araştırma
}

\author{
Perceptions Regarding Prayer: A Metaphorical Study
}

\begin{abstract}
Abdullah Dağcı ${ }^{*}$ (1)
Öz

Üniversite öğrencileri üzerinde yapılan bu araştırma, bireylerin dua etmeye yönelik algılarını tespit etmek amacıyla gerçekleştirilmiştir. Katılımcılara "Dua... gibidir/benzer, çünkü...” ifadesini ve sosyo-demografik değişkenlere dair soruları içeren bir form uygulanmıştır. Bu form aracılığıyla ulaşılan veriler, içerik analizi ile incelenmiştir. 141 katılımcı tarafindan dua etmeye yönelik üretilen metaforlar, ortak özelliklerine göre sınıflandırılmıştır. Araştırmanın sonuçlarına göre örneklem tarafindan dua etmeye yönelik olarak 106 farklı metafor sunulmuştur. Bu metaforlar ortak özelliklerine göre incelenerek 'rahatlama', 'güven bulma', 'tövbe etme', 'manevi gereksinimleri karşılama', 'baş etme', 'yakınlaşma', 'isteme' ve 'diğer' olmak üzere 8 farklı kategori olarak gruplandırılmıştır. Katılımcıların 26'sı 'rahatlama', 22'si 'güven bulma', 20'si 'tövbe etme', 18'i 'manevi gereksinimleri karşılama', 17'si 'baş etme', 15'i 'yakınlaşma', 12'si 'isteme' ve 11 'i 'diğer' kategorilerinde metafor sundukları tespit edilmiştir. Duanın; rahatlama kategorisinde 'konuşma', güven bulma kategorisinde 'maske', tövbe etme kategorisinde 'terapi', manevi gereksinimleri karşılama kategorisinde 'nefes almak', baş etme kategorisinde 'ilaç', yakınlaşma kategorisinde 'emir' ve isteme kategorisinde 'istek mektubu' olarak en fazla algılandığına ulaşılmıştır.
\end{abstract}

\section{Anahtar Kelimeler}

Din Psikolojisi, Dua, Algı, Metafor, Baş Etme

\begin{abstract}
This study, performed on university students, aimed to determine individuals' perceptions with regard to praying. We applied a survey form including the statement "Prayer is like/similar (with)... because..." and questions on sociodemographic variables. The gathered data were analyzed through content analysis. The metaphors produced by 141 participants were divided into 8 categories in respect to common features. One hundred and six different metaphors for praying were presented by the sample. By examining these metaphors, the following categories were created: "relaxing," "trusting," "repenting," "meeting spiritual needs," "coping," "getting closer," "wishing," and "other." In the sample, there were 26 metaphors for "relaxing," 22 for "trusting," 20 for "repenting," 18 for "meeting spiritual needs," 17 for "coping," 15 for "getting closer," 12 for "wishing," and 11 for "other." Praying is perceived as "speech" for relaxing, "mask" for trusting, "therapy" for repenting, "breathing" for meeting spiritual needs, "medicine" for coping, "order" for getting closer, and "request letter" for wishing categories.
\end{abstract}

\section{Keywords}

Psychology of Religion, Prayer, Perception, Metaphor, Copying

\footnotetext{
* Sorumlu Yazar: Abdullah Dağcı (Dr. Öğr. Üyesi), Karamanoğlu Mehmetbey Üniversitesi Edebiyat Fakültesi, Psikoloji Bölümü, Sosyal Psikoloji Anabilim Dalı, Karaman, Türkiye. E-posta: adagci@kmu.edu.tr ORCID: 0000-0003-1540-1256

Attf: Abdullah Dagci, "Duaya ilişkin Algılar: Metaforik Bir Araşttrma." darulfunun ilahiyat 32, 1 (2021): 179-198.
}

https://doi.org/10.26650/di.2021.32.1.819178 


\section{Extended Summary}

In this study, by identifying the perceptions of individuals about prayer, we aimed to categorize their expressions with regard to praying. For this purpose, the study population included students between the ages of 19 and 26 years studying at theology faculties. The research data was obtained by a data collection technique through metaphors. We applied a survey form including the statement "Prayer is like/ similar (with)... because..." and questions on socio-demographic variables (gender, place of residence, and perception of socio-economic level). We then analyzed the obtained data through the content analysis method. For detailed analysis, the data were presented as distributions of frequency (f) and percentage (\%). Of the 173 participants who filled out the questionnaire, 32 of the participants who could not produce metaphors and were thus excluded from the study. We evaluated the data obtained from the remaining 141 participants. The metaphors produced by the 141 participants, in respect to common features, were divided into 8 different categories. The raw data was analyzed in view of the aim of this study, a literature review, and contributions of field experts, and then the categories were determined. By examining the metaphors, the following categories were created: "relaxing," "finding confidence," "repenting," "meeting spiritual needs," "coping," "getting closer," "wishing," and "other." In the sample, there were 26 (18.43\%) metaphors for "relaxing," 22 (15.60\%) for "trusting," 20 (14.8\%) for "repenting," $18(12.76 \%)$ for "meeting spiritual needs," 17 (12.05\%) for "coping," 15 (10.63\%) for "getting closer," 12 (8.51\%) for "wishing," and $11(7.80 \%)$ for "other." Prayer was perceived as "speech" for the relaxing category, "mask" for the trusting category, "therapy" for the repenting category, "breathing" for the meeting spiritual needs category, "medicine" for the coping category, "order" for the getting closer category, and "request letter" for the wishing category.

Within the scope of the generated categories with regard to prayer, the metaphors produced by the participants were as follows: (a) Metaphorizations in the "relaxing" category: speaking, remedy, breathing, hospital, doctor, pouring out, prescription, lung, window, home, listening ney (reed flute), vaccine, Luqmān al-Hakīm, performing ablution, and door of peace. In this category, it was determined more participants tend to perceive prayer as "speaking." (b) Metaphorizations in the "trusting" category: mask, shield, shelter, harbor, hope, guard, castle gate, protection circle, isolation, quilt, umbrella, curtain, armor, and Ottoman. In this category, it was determined that more participants tend to perceive prayer as a "mask." (c) Metaphorizations in the "repenting" category: therapy, cologne, water, eraser, guide for right way, court, bleach, rain, water purifier, spring, soap, iron, sharp knife, and reborn. In this category, it was determined that more participants tend to perceive 
prayer as a "therapy." (d) Metaphorizations in the "meeting spiritual needs" category: breathing, school, bread, gold, air, artery, diamond, tea, bread, food, doping, and heart. In this category, it was determined that more participants tend to perceive prayer as "breathing." (e) Metaphorizations in the "coping" category: medicine, vitamin, Khizr, key, snowdrop, encyclopedia, lifesaver, ointment, teacher, shortcut, and adhesive. In this category, it was determined that more participants tend to perceive prayer as "medicine." (f) Metaphorizations in the "getting closer" category: command, salvation, pole star, magnet, stairs, embrace, elevator, rope, bridge, compass, mountain climbing, and journey. In this category, it was determined that more participants tend to perceive prayer as a "command." (g) Metaphorizations in the "wishing" category: request letter, health, request gate, ocean, soil, sky, and communication tool. In this category, it was determined that more participants tend to perceive prayer as a "request letter." (h) Metaphorizations in the "other" category: tree, car, glass, mirror, oven, bag, foresee, bailment, gift, mirror, and light. The presence of many different metaphors in this category may indicate that various references can be made to prayer. Consequently, when looking at the justification of the metaphors with regard to prayer, it is seen that the participants had a wide range of justifications. In addition, it has been concluded that the metaphors and their justification are in line with their expressions about prayer in the verses of the Holy Qur'an and hadiths. Furthermore, it has been determined that there are similarities between the classifications of prayer in related studies on prayer and the comprised categories in the present study. 


\section{Giriş}

Yaratıcı ile insan arasındaki ilişkiden doğan duanın, ilk insandan bu yana her toplumda var olduğu söylenebilir. İçerik, şekil ve uygulamalar bakımından farklılık gösterse de duanın; yalvarma, sıkıntılar ile baş etmek için yardım isteme, sahip olunanlar için şükretme, rahatlamak için sığınma gibi amaçlarla yapıldığı ifade edilebilir. Bu sayede inanan insan kendisinden daha güçlü bir varlığa kendini açar, destek bulabileceğini hissederek umutlanır, dualarına cevap veren birinin olduğunu düşünerek yalnızlık hissinden uzaklaşır ve insan olarak sınırlı olduğunun bilincinde olarak sınırsız güce sahip bir varlığa sığınır. Bu nedenle insanlık tarihinin her döneminde aşkın bir varlık ile insan arasında duanın önemli bir yere sahip olduğu söylenebilir.

Duanın nerede, ne zaman ve nasıl yapılacağına dair dinlerde yönlendirmeler bulunur. İslami açıdan dua, zaman ve mekân fark etmeksizin, kendi başına ya da bir toplulukla yapılabilirken; ilksel dinlerde duanın genellikle topluluk halinde ve kutsal olarak kabul edilen belli yerlerde ve belli zaman dilimlerinde yapıldığı söylenebilir. Bazı dinlerde ise dizleri üzerinde durma, yere kapanma, avuçlarını semaya kaldırma, müzik aletleri eşliğinde dans etme, ateş etrafinda dönme, topluca kol kola girilerek çeşitli sesler çıkarma vb. dua etme şekilleri de bulunur. Diğer yandan içerik açısından bakıldığında, problemlerle baş etme ve bir şeye sahip olmak için talepte bulunmanın dua etmeye yönelten faktörlerin başlıcaları olduğu söylenebilir.

Kişilik gelişimine etki eden dua; intihar düşünceleri, depresyon eğilimi gibi problemlerin üstesinden gelmeye destek olur. ${ }^{1}$ Huzurlu bir hayat sürmeye katk1 sağlayan dua; olumsuz yaşam olaylarının etkilerini azaltıcı bir etkiye sahip olduğu için insan hayatının her aşamasında işlevseldir. ${ }^{2}$ Dua; sınırlılı̆̆ını ve bazı durumlarda çaresizliğini hisseden insanın ayrılmaz bir parçasıdır. ${ }^{3}$ Dua etme hem olumsuz yaşam olayları ile başa çıkmaya yardımcı olur ${ }^{4}$ hem de kimlik bunalımlarının üstesinden gelerek sağl1klı bir kimlik oluşumunu destekler. ${ }^{5}$

1 Mehmet Ayas, "Dua Öğretiminin Birey Üzerindeki Etkileri ve Değerler Eğitimine Katkıları”, Gaziosmanpaşa Üniversitesi İlahiyat Fakültesi Dergisi 1, sy. 2 (2013): 73-96.

2 Feim Gashi, "Dua ve Hayat Memnuniyeti Üzerine Karşılaştırmalı Bir Araştırma”, Uludă Üniversitesi Illahiyat Fakültesi Dergisi 25, sy. 2 (2016): 1-29.

3 Mesut Erdal, “Kur'an'daki Bazı Dualar Üzerine Mülahazalar”, Dicle Üniversitesi İlahiyat Fakültesi Dergisi 1, (1999): 231-246; Hasan Kayıklı,, "Kur'an'daki Dualar Üzerine Psikolojik Bir Değerlendirme", Çukurova Üniversitesi İlahiyat Fakültesi Dergisi 1, sy. 1 (2001): 135-160.

4 Y. Emre Temiz, "İlk Yetişkinlik Dönemindeki Bireylerde Dua ve Başa Çıkma Tarzları Arasındaki İlişkinin İncelenmesi”, Bülent Ecevit Üniversitesi İlahiyat Fakültesi Dergisi 6, sy. 1 (2019): 177206; Y. Emre Temiz, "Yetişkinlerde Dini Başa Çıkma Yöntemi Olarak Dua” (Yüksek Lisans Tezi, Sakarya Üniversitesi, Sosyal Bilimler Enstitüsü, 2014).

5 Mustafa Koç, "Din Psikolojisi Açısından Ergenlik Döneminde Dua ve İbadet Psikolojisinin Gelişimi”, Ekev Akademi Dergisi 9, sy. 25 (2005): 75-88. 
İslamî açıdan duaya bakıldığında Kur'an'da; dua edenin Allah katında kıymetinin artacağ $1^{6}$, sadece sıkıntı anında değil hayatın her anında dua edilmesinin gerektiği ${ }^{7}$; Allah'a yalvarılması ve takva ile dua edilmesinin önemli olduğ ${ }^{8}$; dualara Allah'1n yanıt vereceği ${ }^{9}$ gibi birçok ifade bulunur. Hadislerde ise ibadetlerin temelinin dua olduğ $\mathrm{u}^{10}$ ve Allah'ın fazlından istenmesi gerektiğ $\mathrm{i}^{11}$ belirtilir.

Hem psikolojik hem de dini bir yönü olan dua, farklı açılardan değerlendirilmiştir. $\mathrm{Bu}$ bağlamda duanın din psikolojisi alanının başlıca çalışma konularından biri olduğu söylenebilir. Bu alandaki araştırmacılar, dua konusuna önem vermişler ve dua etmeyi şekil, amaç, içerik vb. bakış açılarından incelemek üzere çeşitli çalışmalar yapmışlardır. Duayı tanımlamaya yönelik girişimlere bakıldığında; 'kuldan Allah'a doğru yapılan sözlü veya fiili çağrı'12; 'inanan insanın Allah'a yönelişini ve bağlanışını yansıtan her türlü duygu, dilek, talep, tutum, yakarış ve tapınmanın bir yansıması ve ifadesi' '13; 'insanın maddî veya manevî dileğini Allah'a sunması, insanın kalbinin Allah'a yönelmesi, O'nunla konuşması ve O'nun yardımını istemesi'; ${ }^{14}$ 'kutsal kabul edilen güç ile konuşma veya spiritüel bir paylaşım biçimi'; ${ }^{15}$ 'kutsal ya da aşkın bir varlık ile kurulan manevî bir irtibat ${ }^{\prime 16}$ şeklinde dua tanımlamaları olduğu görülür.

Yaşam memnuniyetine olumlu yansımaları olan dua, pozitif duyguları destekleyici ve negatif duyguları ise önleyici bir etkiye sahiptir. Bu nedenle inanan insanın hayatında ömür boyu var olacak bir argüman olarak düşünülebilir. ${ }^{17}$ Dua etme,

6 Kur'an Yolu (Erişim 15 Ekim 2020), Furkan, 25/77.

7 Yûnus, 10/12.

8 A'raf, 7/205.

9 Mü'min, 40/60; Neml, 27/62.

10 Ebû Îsâ Muhammed b. Îsâ b. Sevre (Yezîd) et-Tirmizî, el-Câmi 'u ’ṣ-șahîhh, nşr. Ahmed M. Şâkir, (Kahire: Yayınevi Yok, 1356/1937), "Deâvât", 1.

11 Tirmizî, "Deâvât", 126.

12 Fevzi Zülaloğlu, Kur'an'da Dua ve Rasullerin Dua Örnekleri (İstanbul: Ekin Yayınları 2011), 35.

13 Hayati Hökelekli, İslam Psikolojisi Yazıları (İstanbul: Değerler Eğitimi Merkezi Yayınları, 2012), 65 .

14 Vecdi Akyüz, Kur'an ve Sünnet 'te Dua ve Yakarışlar (İstanbul: Rağbet Yayınları, 2011), 19.

15 Ahmet Albayrak, Üniversite Gençlerinin Dua Tutum ve Davranışları (Rize: Karadeniz Basın Yayıncılık, 2009).

16 Abdullah Dağcı, "Amaçsal Açıdan Dua Türleri: Din Psikolojisi Bağlamında Tümevarımsal Bir Yaklaşım Denemesi”, Eskişehir Osmangazi Üniversitesi Illahiyat Fakültesi Dergisi 5, sy. 8 (2018): 87-120.

17 Gashi, "Dua ve Hayat Memnuniyeti Üzerine Karşılaştırmalı Bir Araştırma”. 
çocukluk döneminden yaşl11ık dönemine kadar bütün hayatı psiko-sosyal açıdan kuşatan bir işleve sahiptir. Çocukluk döneminde çocuğa dua etmenin öğretilmesi gelişim ödevleri ile uyumlu bir dua anlayışının oluşmasını sağlar. ${ }^{18} \mathrm{Bu}$ dönemde dua, bir yandan çocukları psikolojik olarak desteklerken diğer yandan güven duygusunu güçlendirerek onların bireyleşmelerine ve sosyalleşmelerine yardımcı olur. ${ }^{19}$ Buhranların yaşandığı bir evre olan ergenlikte dua hem kimlik bunalımlarının üstesinden gelmeyi hem de olumlu kişilik gelişimini destekleyerek düzenleyici ve dengeleyici bir işlev görür. ${ }^{20}$ Kişilik oluşumunda önemli fonksiyonlar oynayan dua; intihar, depresyon gibi psikolojik temelli problemlerin üstesinden gelmeyi destekler. Dua etme; inanan insanın Allah'a daha da yakınlaşmasına, acizliğini aşmasına ve çaresizlik duygularının üstesinden gelmesine yardımcı olur. ${ }^{21} \mathrm{Bu}$ nedenle dua etme insan hayatının özellikle zorlu zamanlarında gerekli olan ve insandan ayrı düşünülemeyecek bir konudur. ${ }^{22}$ Dua; insanların içsel huzur sağlamalarına, hayatlarını daha uygun bir hale getirmelerine, geleceğe umutla bakmalarına ve olumsuz yaşam olayları karşısında dayanıklı olmalarına destek olur. ${ }^{23}$

Dua ile ilgili araştırmalarda dua etmeye farklı bakış açılarından yaklaşılmış ve duaya yönelik birtakım sınıflandırmalar yapılmıştır. Ulaşılan araştırmalardaki bu sinıflandırmalar tablo 1'de sunulmuştur.

18 Esra Türk, "Din Eğitimi Açısından Çocukluk Döneminde Dua Kavramının Önemi”, İslam Medeniyeti Araştırmaları Dergisi 1, sy. 1 (2015): 445-471.

19 M. Doğan Karacoşkun, "Okul Öncesi Dönem Çocuklarında Dua", Cumhuriyet Üniversitesi Illahiyat Fakültesi Dergisi 9, sy. 1 (2005): 101-124.

20 Koç, "Din Psikolojisi Açısından Ergenlik Döneminde Dua ve İbadet Psikolojisinin Gelişimi".

21 Kayıklık, "Kur'an'daki Dualar Üzerine Psikolojik Bir Değerlendirme”.

22 Erdal, “Kur'an'daki Bazı Dualar Üzerine Mülahazalar”.

23 Resul Ertuğrul, “Kur'ân'da Fiilî Dua”, İnsan ve Toplum Bilimleri Araştırmaları Dergisi 4, sy. 4 (2015): 896-921. 
Tablo 1.

Duaya İlişkin Yapılmış Sınıflandırmalar

\begin{tabular}{|c|c|c|}
\hline Araştırma & \multicolumn{2}{|c|}{ Kategoriler } \\
\hline $\begin{array}{l}\text { Hökelekli } \\
\text { (2012) }\end{array}$ & $\begin{array}{l}\text { a-hamd ve şükür duası, } \\
\text { b-tapınma ve Allah'1 ululama } \\
\text { duası, } \\
\text { c-korunma ve sığınma duası, } \\
\text { d-tevekkül ve inâbe duası } \\
\end{array}$ & $\begin{array}{l}\text { e-istirca duası, } \\
\text { f-tevbe, af ve bağışlanma duası, } \\
\text { g-yardım, imdat ve kurtuluş duası, } \\
\text { h-talep ve istek duası. }\end{array}$ \\
\hline Yapıc1 (2005) & $\begin{array}{l}\text { a-Allah’tan yardım isteme } \\
\text { b-sağlıklı olma ve kötülüklerden } \\
\text { korunma başta olmak üzere } \\
\text { bireysel taleplerin gerçekleşmesi } \\
\text { c-ailenin sağlıklı, mutlu ve } \\
\text { huzurlu olmasını arzulama } \\
\text { d-sevdikleri ve korktukları Allah } \\
\text { ile iletişim kurma ve içsel huzur }\end{array}$ & $\begin{array}{l}\text { e-dini açıdan dua etmenin bir gereklilik, } \\
\text { ibadet ve sevap olduğu düşüncesi } \\
\text { f-Allah'a şükretme } \\
\text { g-günahların affedilmesi ve uhrevi mutluluk } \\
\text { arzusu } \\
\text { h-tüm insanların iyiliğini isteme ve kolektif } \\
\text { huzur }\end{array}$ \\
\hline $\begin{array}{c}\text { Albayrak } \\
\text { (2007) }\end{array}$ & $\begin{array}{l}\text { 1) Dış güdümlü dua formları: } \\
\text { a-talep etme duası, } \\
\text { b-alışkanlık biçimi duası, } \\
\text { c-başa çıma duası. }\end{array}$ & $\begin{array}{l}\text { 2) İc güdümlü dua formları: } \\
\text { a-itiraf etme ve bağışlanma duası, } \\
\text { b-şükür duası, } \\
\text { c-şefaat duası, } \\
\text { d-ibadet ve yaratıcıya tapınma duası, } \\
\text { e-tefekkür ve rûhî gelişme duası } \\
\end{array}$ \\
\hline $\begin{array}{l}\text { Horozcu } \\
(2010)\end{array}$ & $\begin{array}{l}\text { 1) İçerik bakımından dua türleri: } \\
\text { a-istek duas1, } \\
\text { b-şükür duas1, } \\
\text { c-övgü ve yüceltme duası, } \\
\text { d-tövbe, af ve günah çıkarma } \\
\text { duas1. }\end{array}$ & $\begin{array}{l}\text { 2) Yapılış üslubuna göre dua türleri: } \\
\text { a-özgün dua ve formel dua, } \\
\text { b-törensel dua ve bireysel dua, } \\
\text { c-düşünsel dualar, } \\
\text { d-takdirî dua ve tevcihî dua, } \\
\text { e-samimi hitap duası }\end{array}$ \\
\hline Dağcı (2018) & $\begin{array}{l}\text { 1) Yalıtım ve yalnızlık } \\
\text { a-acizliğini belirtme } \\
\text { b-yalnızlığını giderme } \\
\text { c-iletişim kurma } \\
\text { 2) Anlamsızlık, hayatın anlamı ve } \\
\text { amacı } \\
\text { a-rahatlama } \\
\text { b-manevî açıdan güçlenme }\end{array}$ & $\begin{array}{l}\text { 3) Özgürlük, sorumluluk ve isteme } \\
\text { a-istekte bulunma } \\
\text { b-yardım isteme } \\
\text { c-güvende hissetme } \\
\text { 4) Ölüm, umut, var olmaya devam etme } \\
\text { a-ihtiyaç duyma } \\
\text { b-teselli bulma } \\
\text { c-şükretme } \\
\text { d-günahlardan bağışlanma }\end{array}$ \\
\hline $\begin{array}{c}\text { Udis-Kessler } \\
\text { (1998) }\end{array}$ & $\begin{array}{l}\text { a-talep duas1 } \\
\text { b-övgü duası, } \\
\text { c-şükür duas1, } \\
\text { d-kutsal kitap ile dua } \\
\text { e-şefaat edici dua }\end{array}$ & $\begin{array}{l}\text { f-teslim olma duası } \\
\text { g-itiraf ve tövbe duas1 } \\
\text { h-ayinsel dualar, } \\
\text { 1-derin düşünme duas1/meditasyon, } \\
\text { i-kutsama duası }\end{array}$ \\
\hline
\end{tabular}

Tablo 1'de görüldüğü üzere dua; şekil, içerik, amaç vb. açılardan sınıflandırılmıştır. Dua Hökelekli ${ }^{24}$ tarafından sekiz başlıkta ele alınmışken, Albayrak ${ }^{25}$ tarafından ise iç güdümlü ya da dış güdümlü olup olmaması bakımından bir tasnif yapılmıştır.

24 Hökelekli, İslam Psikolojisi Yazıları.

25 Ahmet Albayrak, "Dindarlık Tipleri Açısından Dua Formları", Marife 7, sy. 2 (2007): 189-201. 
Bunun yanında Horozcu ${ }^{26}$ içerik ve üslup bakımından duayı incelemiş, UdisKessler $^{27}$ ise dua etmeyi on başlıkta ele almıştır. Son olarak Dağc1 ${ }^{28}$ ise duay amaç bakımından ele almış, dua etmeye varoluşsal açıdan bir yaklaşım sunmuş ve buna göre dört ana başlıkta duayı incelemiştir. Dua etmeye ilişkin bu yaklaşımlar ve sinıflandırmalar gözden geçirildikten sonra, üniversite öğrencilerinin duaya ilişkin algıları üzerinde bir araştırma yapılmasının ve elde edilen veriler üzerinden dua etmenin kategorilendirilmesinin dua ile ilgili alanyazına farklı bakış açıları getirebileceği düşünülmüştür. Dolayısıyla araştırma kapsamında ulaşılan sonuçlar, dua etmeye ilişkin sınıflandırma yaptığ için alana önemli bir katkısının olacağı söylenebilir.

\section{Araştırmanın Amacı}

Araştırmanın amacı üniversite öğrencilerinin duaya ilişkin algılarını metaforlar yardımıyla incelemektir. Bu bağlamda araştırmada şu sorulara yanıtlar aranmıştır: 1) Üniversite ögrencilerinin duaya ilişskin algılarını nitelemede başvurdukları metaforlar nelerdir? 2) Üniversite ögrencilerinin duaya ilişkin ürettiği metaforların ortak özellikleri dikkate alınarak ne tür kategoriler oluşturulabilir? Araştırma bu iki soru üzerinde temellendirilmiş, elde edilen verilerin analizleri bu bağlamda gerçekleştirilmiş ve sonuçlar değerlendirilirken bu çerçeve göz önünde bulundurulmuştur.

\section{Yöntem}

Araştırmanın evreni üniversitelerin ilahiyat fakültelerinde öğrenim gören 19 ile 26 yaş arası öğrencilerden; araştırmanın örneklemi ise araştırmaya gönüllü olarak katılan 141 katılımcıdan oluşmaktadır. Araştırmanın üniversite öğrencileri üzerinde yapılmasının nedeni daha nitelikli ve anlaşılır veriler toplamaktır. Araştırmaya katılan bireylere dair sosyo-demografik bilgiler Tablo 2'de sunulmuştur.

26 Ümit Horozcu, Din Psikolojisi Açısından Dünyevi İstek Duaları (Doktora Tezi, İstanbul Üniversitesi, Sosyal Bilimler Enstitüsü, 2010).

27 Amanda Udis-Kessler, "Heartwork: A Loving Meditation on Various Forms of Prayer", Whosoever 3, sy. 3 (1998).

28 Dağcı, "Amaçsal Açıdan Dua Türleri”. 
Tablo 2.

Sosyo-Demografik Özelliklerine Göre Katılımcıların Dă̆ılımı

\begin{tabular}{|c|c|c|c|c|}
\hline \multicolumn{2}{|r|}{ Değişken } & & $f$ & $\%$ \\
\hline \multirow{3}{*}{1} & \multirow{3}{*}{ Cinsiyet } & $\mathrm{K}_{12}$ & 81 & 57.5 \\
\hline & & Erkek & 60 & 42.5 \\
\hline & & Toplam & 146 & 100 \\
\hline \multirow{4}{*}{2} & \multirow{4}{*}{ Yerleşim yeri } & Köy/Kasaba & 36 & 25.5 \\
\hline & & İlçe & 42 & 29.8 \\
\hline & & İl Merkezi & 63 & 44.7 \\
\hline & & Toplam & 146 & 100 \\
\hline \multirow{4}{*}{3} & \multirow{4}{*}{ Sosyo-ekonomik durum algisı } & Alt & 39 & 27.7 \\
\hline & & Orta & 77 & 54.6 \\
\hline & & Üst & 25 & 17.7 \\
\hline & & Toplam & 141 & 100 \\
\hline
\end{tabular}

Tablo 2'ye göre, katılımcılar arasındaki kızların sayısının, erkeklerden daha fazla olduğu, en çok katılımcının il merkezlerinde ikamet ettiği ve katılımcıların yarısından fazlasının kendisini sosyo-ekonomik düzey olarak orta düzeyde algıladığg görülmektedir. Araştırma verileri değerlendirilirken bu sosyo-demografik değişkenler de göz önünde bulundurulmuştur.

\section{Verilerin Toplanması ve Analizi}

Araştırmaya başlamadan önce resmî makamlardan etik kurul raporu alınmış ve katılımcılar onam formunu doldurduktan sonra soruları cevaplamışlardır. Çalışmadaki veriler, yarı-açık uçlu cümle doldurma tekniği ile elde edilmiştir. $\mathrm{Bu}$ teknik kullanılarak gerçekleştirilen diğer çalışmalar ${ }^{29}$ incelenmiş ve "Dua... gibidir/benzer, çünkü...” cümlesini ve sosyo-demografik değişkenleri (cinsiyet, yerleşim yeri, sosyo-ekonomik durum algısı) içeren bir form katılımcılara online olarak uygulanmıştır. Bu cümlede 'çünkü’ bağlacının kullanılmasının amacı, duaya ilişkin sunulan metaforların gerekçelerine de ulaşmaktır. Nitel kapsamda yapılan bu araştırmanın geçerliğini ve güvenirliğini sağlamak için alan uzmanlarının görüşlerine başvurulmuştur. Diğer yandan elde edilen verileri açıklamak ve ilişkilere ulaşmak için veri analizi yapılmıştır. Bu sayede ortak niteliklere sahip veriler bir araya getirilerek, sınıflandırmaya gidilmiştir.

Çalışma kapsamında 173 katılımcı anket formunu doldurduğu halde, metafor üretemeyen 32 katılımeının formu araştırmaya dahil edilmemiş ve 141 anket

29 Abdullah Dağc1 - Saffet Kartopu, "University Students' Perceptions Regarding The Holy Qur'an: A Metaphorical Study on Muslim Turk Sample”, Turkish Studies 11, sy. 7 (2016): 101120; Saffet Kartopu - Abdullah Dağc1, "Üniversite Öğrencilerinin Hz. Muhammed'e Yönelik Algıları: Metaforik Bir Araştırma”, The Journal of Academic Social Science Studies 34, sy. 2 (2015): 217-235. 
formundan elde edilen veriler değerlendirmeye tabi tutulmuştur. Ulaşılan veriler öncelikle Excel programına transfer edilerek ortak özellikleri bakımından kategoriler oluşturulmuştur. Değerlendirmelerin daha iyi analiz edilebilmesi için elde edilen bu veriler, frekans (f) ve yüzde (\%) dağılımları üzerinden sunulmuştur.

\section{Bulgular ve Tartışma}

Elde edilen ham veriler; araştırmanın amaçları, alanyazın taraması ve alan uzmanlarının katkıları ile analiz edilerek kategoriler belirlenmiştir. Katılımcıların ürettiği metaforlar üzerinden elde edilen verilerden yola çıkılarak oluşturulan kategoriler ile bu metaforların bütün kategoriler içindeki dağılımları frekans ve yüzde olarak Tablo 3’te verilmiştir.

\section{Tablo 3.}

Oluşturulan Kategorilere Metaforların Dağılımı

\begin{tabular}{|c|c|c|c|c|c|c|}
\hline & Kategoriler & $f$ & $\%$ & Metaforlar & $f$ & $\%$ \\
\hline 1 & Rahatlama & 26 & 18,43 & $\begin{array}{l}\text { Konuşma (4), derman (3), teneffüs (3), } \\
\text { hastane (3), doktor (2), içini dökmek } \\
\text { (2), reçete, akciğer, pencere, ev, ney } \\
\text { dinlemek, aş1, Lokman Hekim, abdest } \\
\text { almak, huzur kapis1 }\end{array}$ & 15 & 14,15 \\
\hline 2 & Güven bulma & 22 & 15,60 & $\begin{array}{l}\text { Maske (4), kalkan (3), sı̆ğınak (2), } \\
\text { liman (2), umut (2), bekçi, kale kapısı, } \\
\text { koruma çemberi, izolasyon, yorgan, } \\
\text { şemsiye, perde, zirh, Osmanl }\end{array}$ & 14 & 13,20 \\
\hline 3 & Tövbe etme & 20 & 14,18 & $\begin{array}{l}\text { Terapi (4), kolonya (2), su (2), silgi } \\
\text { (2), hidayet rehberi, mahkeme, çamaşır } \\
\text { suyu, yağmur, su arıtma cihazı, bahar, } \\
\text { sabun, ütü, keskin bıçak, yeniden } \\
\text { doğmak }\end{array}$ & 14 & 13,20 \\
\hline 4 & $\begin{array}{l}\text { Manevi } \\
\text { gereksinimleri } \\
\text { karşılama }\end{array}$ & 18 & 12,76 & $\begin{array}{l}\text { Nefes almak (4), okul (3), yemek (2), } \\
\text { altın, hava, atardamar, elmas, çay, } \\
\text { ekmek, gida, doping, kalp }\end{array}$ & 12 & 11,32 \\
\hline 5 & Baş etme & 17 & 12,05 & $\begin{array}{l}\text { İlaç (4), vitamin (2), Hızır (2), anahtar } \\
\text { (2), kardelen, ansiklopedi, can simidi, } \\
\text { merhem, ögretmen, kestirme yol, } \\
\text { yapıştırıcı }\end{array}$ & 11 & 10,37 \\
\hline 6 & Yakınlaşma & 15 & 10,63 & $\begin{array}{l}\text { Emir (3), kurtuluş (2), kutup yıldızı, } \\
\text { mıknatıs, merdiven, kucaklaşma, } \\
\text { asansör, ip, köprü, pusula, dağa } \\
\text { tırmanmak, yolculuk }\end{array}$ & 12 & 11,32 \\
\hline 7 & İsteme & 12 & 8,51 & $\begin{array}{l}\text { İstek mektubu (3), sağlık (2), istek } \\
\text { kapıs1 (2), okyanus, toprak, gökyüzü, } \\
\text { iletişim aracı }\end{array}$ & 7 & 6,60 \\
\hline 8 & Diğer & 11 & 7,80 & $\begin{array}{l}\text { Ağaç, araba, gözlük, ayna, firın, çanta, } \\
\text { geleceği görmek, emanet, hediye, ayna, } \\
\text { 1şık }\end{array}$ & 11 & 10,37 \\
\hline & Toplam & 141 & 100 & & 106 & 100 \\
\hline
\end{tabular}


Tablo 3 hem duaya yönelik geliştirilen 141 metaforun 8 kategoriye dağılımını hem de metaforların kategoriler içindeki frekans ve yüzdelerinin dağılımını göstermektedir. Buna göre katılımcıların \%18,43'ü (n:26) 'rahatlama', \%15,60'1 (n:22) 'güven bulma', \%14,18'i (n:20) 'tövbe etme', \%12,76's1 (n:18) 'manevi gereksinimleri karşılama', \%12,05'i (n:17) 'baş etme', \%10,63'ü (n:15) 'yakınlaşma', \%8,51'i (n:12) 'isteme', \%7,80'i (n:11) 'diğer' kategorilerinde temsil edilmişlerdir. $\mathrm{Bu}$ kategorilerde yer alan metaforların sunulma gerekçelerine dair değerlendirmeler aşağıda sunulmuştur.

\section{Rahatlama Aracı Olarak Algılama}

26 katılımcı bu kategoride 15 farklı metafor üretmiştir ve konuşma (n:4), örneklem tarafindan en çok dile getirilen metafordur. Bu kategoride sunulan metaforların gerekçelerinden bazıları şunlardır:

"Dua etmeden yaşayamayız.", "Dua edince dinleniriz.", "Dua edince ruhumuz huzurla dolar.",

"Dua ederken Allah’a içimizi dökeriz.", "Duayla rahat bir nefes alınır.", "Ruhun gıdasıdır.”, "Ne kadar sık dua edersek o kadar çok rahatlarız.", "Rahatsızlıkları ortadan kaldırı..", "Hastanede fiziksel olarak tedavi olduğumuz gibi duada da manevi olarak tedavi oluruz.", "Manevî mutluluğu duayla yakalarız."

Kur'an'da Hz. Musa'nın hem zulmedenlerden kurtulmak için Allah'a dua ettiğ $i^{30}$ hem de dini tebliğ etme esnasında işini kolaylaştırması, dilini açması ve kalbine ferahlık vermesi için Allah'a niyazda bulunduğu ${ }^{31}$ belirtilir. Diğer yandan Hz. Peygamber, makbul olan üç duadan birinin mazlumun duasının olduğunu ${ }^{32}$ ve yapılan duaları Allah'ın boş çevirmeyeceğini ${ }^{33}$ dile getirir. Katılımcılar tarafından 'rahatlama' kategorisinde üretilen metaforlar ile bu ayetlerin ve hadislerin paralellik gösterdiği ifade edilebilir. Diğer yandan üniversite öğrencilerinin duaya ilişkin algıları üzerinden araştırma kapsamında belirlenen 'rahatlama' kategorisinin Hökelekli'nin (2012) 'istirca duası', Dağcı'nın (2018) 'rahatlama' ve Yapıc1'nın (2005) 'sevdikleri ve korktukları Allah ile iletişim kurma ve içsel huzur' kategorileriyle paralellik gösterdiği söylenebilir.

\section{Güven Bulma Aracı Olarak Algılama}

22 katılımcı bu kategoride 14 farklı metafor üretmiştir ve maske (n:4), örneklem tarafindan en çok dile getirilen metafordur. Bu kategoride sunulan metaforların gerekçelerinden bazıları şunlardır:

30 Kasas, 28/21.

31 Tâhâ, 20/25-28.

32 Tirmizî, "Deâvât", 47.

33 Tirmizîi, "Deâvât", 118. 
"Dua bizi kötülüklerden korur.”, “Dua sayesinde emniyette oluruz.”, “Allah'ın her an yanımızda olduğunu hissederiz", "Olaylar Allah ile aramızda sır kalır.", "İçinden çıkılamayacak durumlarda Allah’a sığınırız.”, "Güvende olduğumuzu hissetmemizi sağlar.”, "Allah ile insanı birbirine bağlar.”, "Dua eden manevî açıdan güvende olur.”, "Zarar verici şeylerden insanı korur.”, "Kendini güvende hissettirir.”, "Dünyanın kötülüklerinden Allah’a sığınırız."

Hz. Peygamber karşılaşılabilecek sıkıntıların dua edilerek önlenebileceğini belirtmiş, ${ }^{34}$ yolculukta ortaya çıkabilecek sorunlardan ve olumsuzluklardan korunmak için Allah'a sığınılması tavsiyesinde bulunmuş ${ }^{35}$ ve Allah'a dua ederken tevekkül inancıyla dua etmiştir. Katılımcılar tarafindan 'güven bulma' kategorisinde üretilen metaforlar ile bu iki hadisin paralellik gösterdiği ifade edilebilir. Diğer yandan üniversite öğrencilerinin duaya ilişkin algıları üzerinden araştırma kapsamında belirlenen 'güven bulma' kategorisinin Hökelekli'nin (2012) 'korunma ve siğınma duast', Dağcl'nın (2018) 'güvende hissetme' ve Udis-Kessler'in (1998) 'teslim olma duası' kategorileriyle paralellik gösterdiği söylenebilir.

\title{
Tövbe Etme Aracı Olarak Algılama
}

20 katılımcı bu kategoride 14 farklı metafor üretmiştir ve terapi (n:4) örneklem tarafından en çok dile getirilen metafordur. Bu kategoride sunulan metaforların gerekçelerinden bazıları şunlardır:

\begin{abstract}
"Günahlarımızı temizler.", "Felaketleri unutarak hayata yeniden başlarız.", "Kimseye söyleyemediğimiz sırlarımızı Allah’a söylediğimiz için sakinleşiriz.”, "Dua edince kalbimizdeki kara lekeler yok olur.", "Yeni doğmuş çocuk gibi günahsız oluruz.”, "İnsanın kalbini temizler.”, "Su gibi dua da insana hayat verir.", "Günahlarımızı temizleyerek kâmil bir müslüman olmayı sağlar.", "Manevî açıdan kirlenenler dua ile arınır", "Günahlardan arındırır.", "Ahiretin var olduğunu insana hatırlatır."
\end{abstract}

Kur'an'da, Allah'tan bağışlanma dileyenlerin Allah katında değerli insanlar olduğ ${ }^{36}$ belirtilirken dua ederken 'bizi affet, bizi bağışla, bize acı' diye dua edilmesi tavsiye edilir. ${ }^{37}$ Bazı ayetlerde de yapılan hatalardan dolayı Allah'tan bağışlanma dilenmesi öğ̈̈tlenirken ${ }^{38}$ gece vakti kalkıp Allah'ın rahmetini umarak

34 Ebü'l-Hüseyn Müslim b. el-Haccâc Müslim, el-Câmi 'u 'ṣ-șahîhh, nşr. Muhammed Fuâd Abdülbâkī (Kahire: Yayınevi Yok, 1374-75/1955-56), "Îmân”, 137.

35 Ebû Abdirrahmân Ahmed b. Şuayb b. Alî en-Nesâî, Sünen, (Beyrut: Daru'l- Kutubi'l- İlmiyye, 1991), "İsti 'âze", 43.

36 Âl-i İmrân, 3/16.

37 Bakara, 2/286.

38 Mü'minûn, 23/118. 
dua edenler ${ }^{39}$ ve bağgşlanma dileyenler ${ }^{40}$ Kur'an'da özellikle övülür. Yine Kur'an'da, Allah'tan bağışlanma dilememiz ve tövbe etmemiz tavsiye edilir. ${ }^{41}$ Diğer yandan $\mathrm{Hz}$. Peygamber'in günahlarının bağışlanması için dua ettiğ $i^{42}$ örnek gösterilir. Katılımcılar tarafından 'tövbe etme' kategorisinde üretilen metaforlar ile bu ayetlerin ve hadisin paralellik gösterdiği ifade edilebilir. Diğer yandan üniversite öğrencilerinin duaya ilişkin algıları üzerinden araştırma kapsamında belirlenen 'tövbe etme' kategorisinin Hökelekli'nin (2012) 'tevbe, af ve bağışlanma duası', Yapıc1'nın (2005) 'günahların affedilmesi ve uhrevi mutluluk arzusu', Albayrak'in (2007) 'itiraf etme ve bağıslanma duası', Horozcu'nun (2010), 'tövbe, af ve günah çıkarma duası', Dağcı'nın (2018) 'günahlardan bağışlanma' ve Udis-Kessler'in (1998), 'itiraf ve tövbe duası' kategorileriyle eşdeğer olduğu söylenebilir.

\section{Manevi Gereksinimleri Karşılama Aracı Olarak Algılama}

18 katılımc1 bu kategoride 12 farklı metafor üretmiştir ve nefes almak (n:4) örneklem tarafindan en çok dile getirilen metafordur. Bu kategoride sunulan metaforların gerekçelerinden bazıları şunlardır:

\footnotetext{
"Dua olmadan bir hayat düşünülemez.", "Ruhumuz duyla beslenir.", "Günün her anında dua edilir.", "Dua sayesinde insanın maneviyatı artar.", "Dua etmek paha biçilmez bir eylemdir.", "Yemek yemeyince nasıl zayıflıyorsak, dua etmeyince de maneviyatımız zayıflar.", "Maneviyatımızı besler.", "Dua olmazsa maneviyat da olmaz.", "Ruhumuzu besler.", "Müslüman hayatı duasız olamaz.", "Nasıl olduğumuzu ve nasıl olmamız gerektiğini duayla anlarız."
}

Kur'an'da, İsa Peygamber'in rızıklandırılmak için Allah'a yalvardığı belirtilmiştir. ${ }^{43}$ Diğer yandan Hz. Peygamber, her türlü gereksinimin Allah'tan istenebileceğini ifade etmiş ${ }^{44}$ ve öfke ile başa çıkmak için duaya yönelmiştir. ${ }^{45}$ Katılımcılar tarafından 'manevi gereksinimleri karşılama' kategorisinde üretilen metaforlar ile bu ayetin ve hadislerin paralellik gösterdiği ifade edilebilir. Diğer yandan üniversite öğrencilerinin duaya ilişkin algıları üzerinden araştırma kapsamında belirlenen 'manevi gereksinimleri karşılama' kategorisinin Yapıcı'nın (2005) 'sağlıklı olma ve kötülüklerden korunma başta olmak üzere bireysel taleplerin gerçekleşmesi’ ve Dağcı'nın (2018) 'ihtiyaç duyma' kategorileriyle benzerlik gösterdiği ifade edilebilir.

39 Zümer, 39/9.

40 Zâriyât, 51/18.

41 Hûd, 11/90.

42 Ebû Abdillâh Ahmed b. Muhammed b. Hanbel eş-Şeybânî Ahmed b. Hanbel, el-Müsned, nşr. Ebû Hâcir Muhammed Saîd Besyûnî (Beyrut: Yayınevi Yok, 1405/1985.), 6/301.

43 Mâide, 5/114.

44 Tirmizî, "Deâvât", 149.

45 Ahmed b. Hanbel, el-Müsned, 6/301. 


\section{Baş Etme Aracı Olarak Algılama}

17 katılımcı bu kategoride 11 farklı metafor üretmiştir. İlaç (n:4), örneklem tarafından en çok dile getirilen metafordur. Bu kategoride sunulan metaforların gerekçelerinden bazıları şunlardır:

"Her türlü rahatsızlığa faydası vardır.", "Sıkıntılı zamanları atlatmaya yardım eder.", "Kriz anlarında hemen imdadımıza yetişir.", "Zorluklarla mücadele etmemize destek olur.", "Karamsarlığa düştüğümüzde bize umut verir.", "Kötümser düşüncelerden kurtulmayı öğretir.", "Yeni umut kapılarının açılmasını sağlar.”, "Zorluklar karşısında hayata sımsıkı bağlanmamızı sağlar.", "Dertleri anında yok eder.", "Sıkıntılarla baş etmeye yardım eder."

Kur'an'da insanların sıkıntı anında Allah'a dua ettiği ve bu sıkıntıdan kurtulunca Allah'a dua etmeyi bıraktıkları belirtilir. ${ }^{46}$ Diğer yandan Hz. Peygamber öfke ile başa çıkmak için dua etmiş ${ }^{47}$ ve hastalıklardan iyileşmek için Allah'a niyazda bulunmuştur. ${ }^{48}$ Yine bu paralelde hastaları ziyaret ederken hastanın iyileşmesi ve şifa bulması için Hz. Peygamber'in Allah'a dua ettiği ve ardından hastanın iyileştiği ${ }^{49} \mathrm{~Hz}$. Peygamber'in Hz. Ali'nin hastalığ için dua ettikten sonra bir daha aynı hastalığa yakalanmadığ $1^{50}$ belirtilmiştir. Bunun yanında Hz. Peygamber, içinden çıkılamayacak sıkıntılarla karşılaş1ırsa "Allah bize yeter, O ne güzel vekildir." denilmesini tavsiye etmiştir. ${ }^{51}$ Katılımcılar tarafından 'baş etme' kategorisinde üretilen metaforlar ile bu ayetin ve hadislerin paralellik gösterdiği ifade edilebilir. Diğer yandan üniversite öğrencilerinin duaya ilişkin algıları üzerinden araştırma kapsamında belirlenen 'baş etme' kategorisinin Hökelekli'nin (2012) 'yardım, imdat ve kurtuluş duası', Albayrak'ın (2007) 'başa çıkma duası' ve Dağcı'nın (208) 'yardım isteme' kategorileriyle yakından ilişkili olduğu söylenebilir.

\section{Yakınlaşma Aracı Olarak Algılama}

15 katılımcı bu kategoride 12 farklı metafor üretmiştir ve emir (n:3) örneklem tarafından en çok dile getirilen metafordur. Bu kategoride sunulan metaforların gerekçelerinden bazıları şunlardır:

"Dua, insana zarar veren şeylerden kurtulmayı sağlar.”, "Dünyalık işleri unuttuğumuz bir andır.”, "Dua eden kurtuluşa erer.”, "Allah’a yaklaşmanın en iyi yoludur.”, "Dua ederken

46 Yûsuf, 10/12, 22.

47 Ahmed b. Hanbel, el-Müsned, 6/301.

48 Ebû Abdillâh Muhammed b. İsmail el-Buhârî, el-Câmi 'u'ṣ-șahîhh, nşr. Muhammed Züheyr b. Nasr (Yayın Yeri Yok: Dâru Tavki'n-Necât, 1422/2001), "Merdâ", 20.

49 Ahmed b. Hanbel, el-Müsned, 1/82, (No: 637).

50 Tirmizî, "Deâvât", 111.

51 Ebû Dâvûd Süleymân b. el-Eş‘as b. İshâk es-Sicistânî el-Ezdî, Sünen, (Riyad: Mektebetu'lMaarif Li'n-Neşri ve’t- Tervi', 1988), "Vitr”, 25. 
Allah'a çok yakın olduğumu hissediyorum.", "Dua edince Allah bizi kendi yanına çeker.", "Dua sayesinde Allah ile iletişim kurarız.", "Dua eden insan her zaman doğru yol üzerindedir.", "Maneviyatımızın güçlenmesini sağlar.", "Mü’minin Allah ile buluştuğu yerdir.”, “Allah’a yakın olduğunu hissettirir.”, “Allah ile bağ kurmamızı sağlar.”

Kur'an'da, duanın sadece Allah'a yapılmas ${ }^{52}$ ve Allah'a içtenlikle ve gönülden dua edilmesi gerektiği,${ }^{53}$ dua edenlere Allah' $1 n$ ayrı bir değer verdiği,${ }^{54} \mathrm{~Hz}$. İshak'ın oğul olarak verilmesinden sonra Hz. İbrahim' in Allah'a şükür duası ettiğ $i^{55}$ belirtilir. Diğer yandan Hz. Peygamber de duanın hem ibadetin özü olduğunu hem de Allah katında en üstün şey olduğunu ${ }^{56}$ ve dua edilerek Allah'a yakınlaşılabileceğini ${ }^{57}$ belirtmiştir. Katılımcılar tarafından 'yakınlaşma' kategorisinde üretilen metaforlar ile bu ayetlerin ve hadislerin paralellik gösterdiği ifade edilebilir. Diğer yandan üniversite öğrencilerinin duaya ilişkin algıları üzerinden araştırma kapsamında belirlenen 'yakınlaşma' kategorisinin Hökelekli'nin (2012) 'hamd ve şükür duast', Albayrak'ın (2007) 'ibadet etme ve yaratıcıya tapınma duası' ve 'şükür duası', Horozcu'nun (2010) ‘övgü ve yüceltme duası' ve 'şükür duası', Dağcı'nın (2018) 'yalnızlı̆̆ını giderme' ve 'şükretme', Yapıcı'nın (2005) 'Allah'a şükretme' ve UdisKessler'in (1998) 'şükretme' kategorileriyle benzerlik gösterdiği ifade edilebilir.

\section{İsteme Aracı Olarak Algılama}

12 katılımcı bu kategoride 7 farklı metafor üretmiştir ve istek mektubu (n:3) örneklem tarafından en çok dile getirilen metafordur. Bu kategoride sunulan metaforların gerekçelerinden bazıları şunlardır:

\footnotetext{
“İsteklerimizi Allah’a dua ile ulaştırırız.”, “Koşulsuz ve şartsız, Allah’tan her zaman yardım isteyebileceğimiz tek vasıtadır.”, “Allah’tan ne talep edersek, bize verilir.", "Güzelliklerin kapısı duayla açılır.", "Malımız duayla bereketlenir.", "Cennet için azığımızı duayla doldururuz.”, "Ne için dua edilirse o verilir.", "Çok değerlidir.”, "Bize yol ve yön gösterir.”, "Hem dünya hem de ahiret mutluluğunu duayla kazanırız.", "Gitmek istediğimiz yönün doğru yön olmasını sağlar.", "Herkes dua etmeyi ister."
}

Kur'an'da, Allah'ın yapılan dualara cevap vereceği $; ;^{58}$ gerçek Müslümanların hayırlı evlatlara sahip olmak için dua ettikleri; ${ }^{59}$ nitelikli bir nesle sahip olmak için

52 Ra'd, 13/14; Şuara, 26/213.

53 Furkān, 25/65.

54 Furkān, 25/77.

55 İbrâhîm, 14/39.

56 Tirmizî, "Deâvât", 1.

57 Müslim, "Salât", 215.

58 Mü'min, 40/60.

59 Furkān, 25/74. 
Hz. Zekeriya ve Hz. İbrahim'in Allah'a yalvardıkları; ${ }^{60}$ Süleyman Peygamber'in hükümranlık kurmak içi Allah'a dua ettiğ $i^{11}$ belirtilir. Diğer yandan Hz. Peygamber, geceleri yapılan dualarda dile getirilen isteklere Allah'ın cevap vereceğini ${ }^{62}$ ve bir şey istenileceği zaman bu isteğin sadece Allah'tan istenmesi gerektiğini ${ }^{63}$ belirtmiştir. Yağmurun yağması için Hz. Peygamber'in dua ettiği ve ardından yağmur yağdığ $1^{64}$ bildirilmiştir. Katılımcılar tarafından 'isteme' kategorisinde üretilen metaforlar ile bu ayetlerin ve hadislerin paralellik gösterdiği ifade edilebilir. Diğer yandan üniversite öğrencilerinin duaya ilişkin algıları üzerinden belirlenen 'isteme' kategorisinin Hökelekli'nin (2012) 'talep ve istek duası', Yapıcı'nın (2005) 'Allah'tan yardım isteme' ve 'tüm insanların iyiliğini isteme ve kolektif huzur', Albayrak' In (2007) 'talep etme duast', Dağc1 (2018) 'istekte bulunma' ve 'yardım isteme', Horozcu'nun (2010) 'istek duası' ve Udis-Kessler' in (1998) 'talep duast' kategorileriyle yakından ilişkili olduğu söylenebilir.

\section{Diğer}

11 katılımcı bu kategoride 11 farklı metafor üretilmiştir. Bu kategoride sunulan metaforların gerekçelerinden bazıları şunlardır:

"Hemen kabul edilmez belki ama mutlaka kabul edileceği bir gün vardır.", "Küçük bir dua edersin ama insana büyük faydaları olur.", "Nereye ulaşmak istiyorsan oraya götürür.", "Olaylara net bir şekilde bakmamızı sağlar.", "Ne için dua edersen eline o geçer.", "Dua edildiğinde yarın güzelliklerle karşılaşacağımızı tahmin ederiz.”, “Mü’min dua ede ede pişer.”, "Bu dünyada ne kadar çok dua edersen ahirete o kadar çok sevap götürürsün."

Katılımcılar tarafindan 'diğer' kategorisinde üretilen metaforlar ve bunların gerekçelerinin de İslamî referanslardaki dua anlayışıyla paralellik gösterdiği ifade edilebilir.

\section{Sonuç}

İnsan hayatında önemli bir yere sahip olan duaya ilişkin farklı yaklaşımlar mevcuttur. Ayrıca benzer bir kültürdeki insanların dua etmeye yükledikleri anlamlar birbirinden farklıdır. Bu nedenle duaya ilişkin algıların metaforlar yoluyla araştırılması, insanların zihninde duanın nasıl bir yer edindiğine dair bilgilere ulaşmaya ve konuya ilişkin daha ayrıntılı veriler elde etmeye yardımcı

60 Âl-i İmrân, 3/38; İbrâhîm, 14/40.

61 Sâd, 38/35.

62 Buhârî, "Deâvât", 13.

63 Tirmizî, "Deâvât", 132.

64 Buhârî, "İstiskâ", 3. 
olur. Bu bağlamda araştırma kapsamında mecazlar yoluyla veri toplama tekniği kullanılarak üniversite öğrencilerinin dua etmeye ilişkin algılarına yönelik veriler elde edilmiştir. Araştırma kapsamında elde edilen veriler hem alanyazındaki dua ile ilişkili araştırmaların verileri hem de alan uzmanlarının katkılarıyla oluşturulan kategorilere yerleştirilmiştir. Buna göre dua etmeye yönelik 141 katılımcı tarafindan 106 farklı metafor geliştirildiği tespit edilmiş ve bu metaforlardan 'rahatlama', 'güven bulma', 'tövbe etme', 'manevi gereksinimleri karşılama', 'baş etme', 'yakınlaşma', 'isteme' ve 'diğer' olmak üzere 8 kategori oluşturulmuştur. Araştırmanın sonuçlarına göre katılımcıların 26's1 'rahatlama', 22'si 'güven bulma', 20'si 'tövbe etme', 18'i 'manevi gereksinimleri karşılama', 17'si 'baş etme', 15'i 'yakınlaşma', 12'si 'isteme' ve 11'i 'diğer' kategorilerinde metafor üretmişlerdir.

Dua etmeye ilişkin oluşturulan kategoriler kapsamında, katılımcıların ürettikleri metaforlar ve bunların arasından en çok tercih edilenler şunlardır: (a) 'Rahatlama' kategorisindeki metaforlaştırmalar: Konuşma, derman, teneffüs, hastane, doktor, içini dökmek, reçete, akciğer, pencere, ev, ney dinlemek, aş1, Lokman Hekim, abdest almak, huzur kapısı. Bu kategoride duayı 'konuşma' olarak algılama eğiliminde olan katılımcıların daha yoğunlukta olduğu tespit edilmiştir. (b) 'Güven bulma' kategorisindeki metaforlaştırmalar: Maske, kalkan, sığınak, liman, umut, bekçi, kale kap1sı, koruma çemberi, izolasyon, yorgan, şemsiye, perde, zırh, Osmanlı. Bu kategoride duayı 'maske' olarak algılama eğiliminde olan katılımcıların daha yoğunlukta olduğuna ulaşılmıştır. (c) 'Tövbe etme' kategorisindeki metaforlaştırmalar: Terapi, kolonya, su, silgi, hidayet rehberi, mahkeme, çamaşır suyu, yağmur, su arıtma cihazı, bahar, sabun, ütü, keskin bıçak, yeniden doğmak. Bu kategoride duay1 'terapi' olarak algılama eğiliminde olan katılımcıların daha yoğunlukta olduğu tespit edilmiştir. (d) 'Manevi gereksinimleri karşılama' kategorisindeki metaforlaştırmalar: Nefes almak, okul, yemek, altın, hava, atardamar, elmas, çay, ekmek, gıda, doping, kalp. Bu kategoride duayı 'nefes almak' olarak algılama eğiliminde olan katılımcıların daha yoğunlukta olduğuna ulaşılmıştır. (e) 'Baş etme' kategorisindeki metaforlaştırmalar: İlaç, vitamin, Hızır, anahtar, kardelen, ansiklopedi, can simidi, merhem, öğretmen, kestirme yol, yapıştırıc1. Bu kategoride duayı 'ilaç' olarak algılama eğiliminde olan katılımcıların daha yoğunlukta olduğu tespit edilmiştir. (f) 'Yakınlaşma' kategorisindeki metaforlaştırmalar: Emir, kurtuluş, kutup yıldızı, mıknatıs, merdiven, kucaklaşma, asansör, ip, köprü, pusula, dağa tırmanmak, yolculuk. Bu kategoride duayı 'emir' olarak algılama eğiliminde olan katılımcıların daha yoğunlukta olduğuna ulaşılmıştır. (g) 'İsteme' kategorisindeki metaforlaştırmalar: İstek mektubu, sağlık, istek kapısı, okyanus, toprak, gökyüzü, iletişim arac1. Bu kategoride duay1 'istek mektubu' olarak algılama eğiliminde olan katılımcıların daha yoğunlukta olduğu tespit edilmiştir. (h) 'Diğer' kategorisindeki 
metaforlaştırmalar: Ağaç, araba, gözlük, ayna, firın, çanta, geleceği görmek, emanet, hediye, ayna, 1şı. Bu kategoride çok farklı metaforların bulunması, dua etmeye çeşitli atıfların yapılabileceğinin bir göstergesi olabilir.

Dua ile ilişkili metaforların gerekçelerine bakıldığında, katılımcıların geniş yelpazede gerekçelendirmeleri olduğu görülür. 'Rahatlama' kategorisinde yaşam kalitesini artırma, psikolojik sağlı̆̆ koruma ve manevi açıdan huzura erme ile ilişkili gerekçeler sunulması, dua etmenin bireyleri rahatlatıcı bir işlevinin olduğuna bir işaret kabul edilebilir. 'Güven bulma' kategorisinde kötülüklerden uzak durma, Allah ile olumlu bağlar kurma ve manevi açıdan güven içinde olma ile ilişkili gerekçeler dile getirilmesi, dua etmenin insanlara güven verici bir fonksiyonunun olduğunun bir göstergesi olabilir. 'Tövbe etme' kategorisinde manevi açıdan temizlenme, hayata tutunma, iyi bir müslüman olma ve ahireti düşünme ile ilişkili gerekçeler beyan edilmesi, bireylerin dua etmeyi tövbe etmek için bir araç olarak kullandıklarına bir referans olabilir. 'Manevi gereksinimleri karşılama' kategorisinde maneviyatı artırma, ruhsal açıdan beslenme ve İslam'a göre hayatı düzenleme ile ilişkili gerekçelerin dile getirilmesi, dua etmenin bireylerin manevi gereksinimlerini karş1lamada önemli bir işleve sahip olduğunun bir göstergesi olabilir. 'Baş etme' kategorisinde hastalıklar, zorluklar ve karamsar düşünceler ile ilişkili gerekçeler sunulması, sıkıntılı süreçlerin üstesinden gelmede dua etmenin önemli bir görev icra ettiğine bir referans olabilir. 'Yakınlaşma' kategorisinde maddiyata meyletmeme, doğru yol üzerinde olma, maneviyatı güçlendirme ve Allah ile olumlu bağlar kurma ile ilişkili gerekçeler beyan edilmesi, dua etmenin Allah'a yakınlaşmayı sağladığına bir işaret olabilir. 'İsteme' kategorisinde her an Allah 'tan yardım isteme, Allah'ın duaları kabul etmesi ve dünya ve ahiret mutluluğu ile ilişkili gerekçeler dile getirilmesi, dua etmenin Allah'tan istekte bulunmada etkin bir şekilde kullanıldığının bir göstergesi olabilir.

Sonuç olarak duaya ilişkin 141 katılımcı tarafindan 106 farklı metafor üretildiği ve bu metaforların 8 kategoride değerlendirilebileceği tespit edilmiştir. Bunun yanında katılımcılar tarafindan sunulan metaforlar ve bu metaforların üretilme gerekçeleri gerek Kur'an ayetlerinde gerekse hadislerde geçen dua ile ilgili ifadelerle paralellik gösterdiğine ulaşılmıştır. Ayrıca dua konusunda yapılan araştırmalardaki dua sınıflandırmaları ile metaforlar üzerinden verileri elde edilen bu araştırmadaki kategorileştirmeler arasında benzerlikler olduğu tespit edilmiştir. Araştırmanın sonuçlarından yola çıkarak şu önerilerde bulunulabilir: Duanın insan hayatındaki işlevinin çeşitli bakış açılarından ele alınabilmesi için farklı örneklemler üzerinde duayla ilişkili araştırmalar yapılabilir. Bu araştırmalar, bireyin hayatında duanın oynadığı roller hakkında, din psikolojisi disiplinine yeni veriler sağlayabilir. 
Hakem Değerlendirmesi: Dış bağımsız.

Çıkar Çatışması: Yazar çıkar çatışması bildirmemiştir.

Finansal Destek: Yazar bu çalışma için finansal destek almadığını beyan etmiştir.

Peer-review: Externally peer-reviewed.

Conflict of Interest: The author has no conflict of interest to declare.

Grant Support: The author declared that this study has received no grant support.

\section{Kaynakça/References}

Ahmed b. Hanbel, Ebû Abdillâh Ahmed b. Muhammed b. Hanbel eş-Şeybânî. el-Müsned. nşr. Ebû Hâcir Muhammed Saîd Besyûnî. Beyrut: Yayınevi Yok, 1405/1985.

Akyüz, Vecdi. Kur'an ve Sünnet te Dua ve Yakarışlar. İstanbul: Rağbet Yayınları, 2011.

Albayrak, Ahmet. "Dindarlık Tipleri Açısından Dua Formları". Marife 7, sy. 2 (2007): 189-201.

Albayrak, Ahmet. Üniversite Gençlerinin Dua Tutum ve Davranışları. Rize: Karadeniz Basın Yayım, 2009.

Ayas, Mehmet. "Dua Öğretiminin Birey Üzerindeki Etkileri ve Değerler Eğitimine Katkıları". Gaziosmanpaşa Üniversitesi İlahiyat Fakültesi Dergisi 1, sy. 2 (2013): 73-96.

Buhârî, Ebû Abdillâh Muhammed b. İsmail. el-Câmi 'u 'ṣ-șahîhh. nşr. Muhammed Züheyr b. Nasr. 8 Cilt. Yayın Yeri Yok.: Dâru Tavki'n-Necât, 2. Basım, 1422/2001.

Dağc1, Abdullah - Kartopu, Saffet. “University Students' Perceptions Regarding The Holy Qur'an: A Metaphorical Study on Muslim Turk Sample”. Turkish Studies 11, sy. 7 (2016): 101-120.

Dağcı, Abdullah. "Amaçsal Açıdan Dua Türleri: Din Psikolojisi Bağlamında Tümevarımsal Bir Yaklaşım Denemesi”. Eskişehir Osmangazi Üniversitesi İlahiyat Fakültesi Dergisi 5, sy. 8 (2018): 87-120.

Ebû Dâvûd, Süleymân b. el-Eş'as b. İshâk es-Sicistânî el-Ezdî. Sünen. Riyad: Mektebetu'l- Maarif Li'n-Neşri ve't- Tervi', 1988.

Erdal, Mesut. “Kur'an'daki Bazı Dualar Üzerine Mülahazalar”. Dicle Üniversitesi İlahiyat Fakültesi Dergisi 1 (1999): 231-246.

Ertuğrul, Resul. “Kur'ân'da Fiilî Dua”. İnsan ve Toplum Bilimleri Araştırmaları Dergisi 4, sy. 4 (2015): 896-921.

Gashi, Feim. "Dua ve Hayat Memnuniyeti Üzerine Karşılaştırmalı Bir Araştırma”. Uludağ Üniversitesi Ilahiyat Fakültesi Dergisi 25, sy. 2 (2016): 1-29.

Horozcu, Ümit. "Din Psikolojisi Açısından Dünyevi İstek Duaları". Doktora Tezi, İstanbul Üniversitesi, Sosyal Bilimler Enstitüsü, 2010. https://tez.yok.gov.tr/UlusalTezMerkezi/ adresinden edinilmiştir.

Hökelekli, Hayati. İslam Psikolojisi Yazıları. İstanbul: DEM Yayınları, 2012.

Karacoşkun, M. Doğan. “Okul Öncesi Dönem Çocuklarında Dua”. Cumhuriyet Üniversitesi İlahiyat Fakültesi Dergisi 9, sy. 1 (2005): 101-124.

Kartopu, Saffet - Dağc1, Abdullah. “Üniversite Öğrencilerinin Hz. Muhammed'e Yönelik Algıları: Metaforik Bir Araştırma”. The Journal of Academic Social Science Studies 34, sy. 2 (2015): 217-235.

Kayıklık, Hasan. “Kur'an'daki Dualar Üzerine Psikolojik Bir Değerlendirme”. Çukurova Üniversitesi Illahiyat Fakültesi Dergisi 1, sy. 1 (2001): 135-160. 
Koç, Mustafa. "Din Psikolojisi Açısından Ergenlik Döneminde Dua ve İbadet Psikolojisinin Gelişimi". Ekev Akademi Dergisi 9, sy. 25 (2005): 75-88.

Kur'an Yolu. Erişim 15 Ekim 2020. https://kuran.diyanet.gov.tr/mushaf

Müslim, Ebü'l-Hüseyn Müslim b. el-Haccâc. el-Câmi 'u 'ṣ-șahîhh. nşr. Muhammed Fuâd Abdülbâkī. Kahire: Yayınevi Yok, 1374-75/1955-56.

Nesâî, Ebû Abdirrahmân Ahmed b. Şuayb b. Alî. Sünen. Beyrut: Daru'l- Kutubi’l- İlmiyye, 1991.

Temiz, Yunus Emre. "Yetişkinlerde Dini Başa Çıkma Yöntemi Olarak Dua”. Yüksek Lisans Tezi, Sakarya Üniversitesi, Sosyal Bilimler Enstitüsü, 2014. https://tez.yok.gov.tr/UlusalTezMerkezi/ adresinden edinilmiştir.

Temiz, Yunus Emre. "İlk Yetişkinlik Dönemindeki Bireylerde Dua ve Başa Çıkma Tarzları Arasındaki İlişkinin İncelenmesi”. Bülent Ecevit Üniversitesi İlahiyat Fakültesi Dergisi 6, sy. 1 (2019): 177-206.

Tirmizî, Ebû Îsâ Muhammed b. Îsâ b. Sevre (Yezîd). el-Câmi 'u'ṣ-șahịhh. nşr. Ahmed M. Şâkir. Kahire: Yayınevi Yok, 1356/1937.

Türk, Esra. “Din Eğitimi Açısından Çocukluk Döneminde Dua Kavramının Önemi”. İslam Medeniyeti Araştırmaları Dergisi 1, sy. 1 (2015): 445-471.

Udis-Kessler, Amanda. "Heartwork: A Loving Meditation on Various Forms of Prayer". Whosoever 3, sy. 3 (1998).

Yapıc1, Asım. "Güdü ve İçerik Açısından Çocuk Duaları ve Dualara Yansıyan Sorunlar". Çukurova Üniversitesi İlahiyat Fakültesi Dergisi, sy. 2 (2005): 57-93.

Zülaloğlu, Fevzi. Kur'an'da Dua ve Rasullerin Dua Örnekleri. İstanbul: Ekin Yayınları, 2011. 